\title{
Distribution of microreticulate dinoflagellate cysts from the Galician and Portuguese coast*
}

\author{
I. BRAVO and I. RAMILO \\ IEO, Centro Oceanográfico de Vigo, Aptdo 1552, 36280 Vigo, Spain.
}

\begin{abstract}
SUMMARY: In May 1993, surface sediment samples from the west coast of the Iberian Peninsula were collected with the aim of studying the geographic distribution of G. catenatum resting cysts. The sampling area ranged from $40^{\circ} 39^{\prime} \mathrm{N}$ (Portugal) to $42^{\circ} 38^{\prime} \mathrm{N}$ (Galicia, Spain). Cysts with exactly the same morphology as G. catenatum were found in a maximum concentration of 504 cysts $\mathrm{cm}^{-3}$ of sediment. Similar cysts but smaller $(24-36 \mu \mathrm{m})$ were found in a maximum concentration of 4488 cysts $\mathrm{cm}^{-3}$ of sediment. A bimodal size distribution of microreticulate cysts from the sediment indicates the probable existence of two cyst species. Differences in the microreticulation of the paracingulum were also observed. We compared the cysts from the sediment with G.catenatum cysts produced in cultures. The study on the distribution of cysts in the sediment also showed significant differences in the vertical profile concentrations of both cyst types. Differences in both the size and microreticulation morphology of the cysts found in the sediment of the continental shelf of Galicia and Portugal are also observed in the literature concerning other countries. The cysts of this species cited for the coasts of Northern Europe present characteristics similar to the cysts referred to in this communication as G. catenatum-like or small microreticulate cysts. The need to clarify the identity of cysts with microreticulation in the wall is discussed in order to identify the geographical distribution of the G. catenatum cyst.
\end{abstract}

Key words: cyst morphology, microreticulate cysts, Galicia, Gymnodium catenatum cyst.

\section{INTRODUCTION}

Gymnodium catenatum Graham is a naked, chain-forming dinoflagellate causing PSP intoxications in several parts of the world (Hallegraeff and Fraga, 1998). It was associated with this type of episode for the first time in Galicia (NW Spain) in 1976, and has frequently been observed since then in these coastal waters and others in a wider area covering the entire west coast of the Iberian Peninsula. The Gymnodium catenatum cyst was first described by Anderson et al., 1988; they reported a brown, spherical 38-60 $\mu \mathrm{m}$ diameter cyst (mean $49 \mu \mathrm{m})$ from incubated plankton samples. These

\footnotetext{
*Received June 3, 1998. Accepted November 11, 1998
}

authors noted the morphological characteristics for the Gymnodinium catenatum cyst which were unique in various aspects. This was the only described dinoflagellate cyst whose external wall has a microreticulation comprising hundreds of polygons measuring 1-3 $\mu \mathrm{m}$. Also, the microreticulation adopts an orientation which reflects the morphological characteristics of the vegetative cell, namely the paracingulum, parasulcus and paracrobase.

After the original description of the G. catenatum cyst, the presence of cysts from this dinoflagellate has been noted in various parts of the world. Identification was based on the microreticulation cited as the main morphological characteristic. The G. catenatum cysts described by Blackburn et al., (1989) 
and Bolch and Hallegraeff (1990) from Tasmania and Matsuoka and Fukuyo (1994) from sediment of Japan have the same morphology and size as in the original description (49 $\mu \mathrm{m}$ mean). Conversely, the cyst described for the north coasts of Europe in recent sediment and in older sediments are somewhat smaller (30-40 $\mu \mathrm{m})$ than that of the original description (Dale et al., 1993; Ellegaard et al., 1993; Nehring, 1995). Bolch and Hallegraeff (1990) noted a third, still smaller, microreticulate cyst (17-22 $\mu \mathrm{m})$, naming it Gymnodium sp. Recent genetic, morphological and ultrastructural studies have demonstrated that there are species other than G. catenatum which produce microreticulate cysts (Bolch et al.,1998; Ellegaard and Moestrup, in press).

This paper describes two types of cysts, with microreticulation in the wall, found in the continental shelf sediment of Galicia and Portugal. A comparison is also made between the morphology and size of these cysts and those of the G. catenatum cyst produced in cultures isolated from Galician waters and those described in the literature.

\section{MATERIAL AND METHODS}

Sediment samples were collected on 24th and 25th May, 1993, in the area shown in Figure 1, between $40^{\circ} 39^{\prime} \mathrm{N}$ (Portugal) and $42^{\circ} 38^{\prime} \mathrm{N}$ (Galicia) at water depths of between 60 and $200 \mathrm{~m}$. A box-corer was used for sampling and, once on board, a cylinder of $20 \mathrm{~cm}$ length $\mathrm{x} 3 \mathrm{~cm}$ base diameter was inserted into the sediment box to extract a subsample. Depending on the percentage of clay/lime matter, the box-corer penetrated to greater or lesser depth in the sediment, obtaining the deepest samples in the limy sediment stations. Therefore, vertical profile resulted in a sediment depth range from 0 to $8-16 \mathrm{~cm}$. Samples of $5 \mathrm{~cm}^{3}$ were processed each $2 \mathrm{~cm}$ to quantify cyst concentrations.

The sediment suspended in filtered sea water was disaggregated with an ultrasonic bath for $10 \mathrm{~min}$ utes, sieved to retain the $20-75 \mu \mathrm{m}$ size fraction, and suspended in $50 \mathrm{ml}$ of distilled water. $10 \mathrm{ml}$ of the suspension was centrifuged at a density gradient using a Ludox TM Colloidal Silica Tech (density of $1.4 \mathrm{~g} \cdot \mathrm{cm}^{-3}$ ). The gradient was performed according to a modification of the technique described by Blanco (1986). In order to avoid osmotic changes in processing cysts, a solution of distilled water with $24 \%$ saccharose was used to perform the gradients and cleansing of the sediment in place of distilled

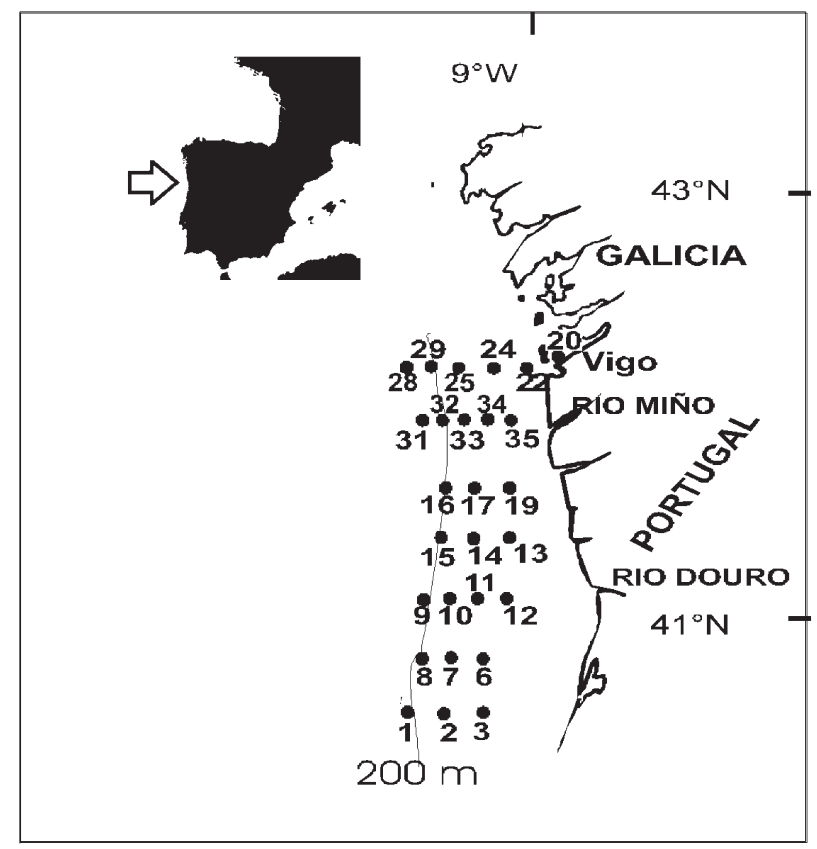

FIG. 1. - Position of the sampling area and stations where sediment samples were collected.

water, as described by that author. The density gradients were carried out in centrifuge tubes of $50 \mathrm{ml}$, where step gradient solutions of $100 \%, 80 \%$ and $60 \%$ Ludox TM were carefully delivered. $10 \mathrm{ml}$ of sediment sample were added and centrifuged at 600 rpm for $15 \mathrm{~min}$. To avoid possible bias in the results of concentrations of the different types of cyst due to their having different densities, all cysts of the whole fraction over $1.4 \mathrm{gr}^{\cdot} \mathrm{cm}^{-3}$ density were counted. In addition, the loss of microreticulate cysts in the fraction remaining at the bottom was observed to be less than $1 \%$.

The fraction separated with the cysts was resuspended in filtered seawater, microreticulate cysts (G. catenatum and $G$. catenatum-like or small microreticulate cysts) and total cysts (no microreticulate cysts included) were counted using the Utermöhl method (Utermöhl, 1958) without fixation.

G. catenatum cysts from culture were obtained by crossing two strains from the culture collection of the Centro Oceanografico de Vigo (Bravo et al., 1998).

\section{RESULTS}

In the sediment samples, two types of cysts were observed with the microreticulation described for $G$. catenatum. Under inverted microscopy, the most 


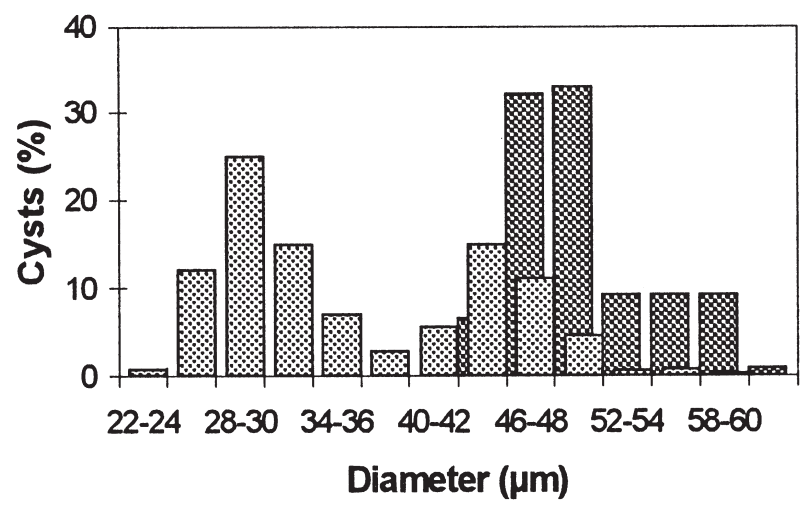

FIG. 2. - Size distribution of cysts, 國 microreticulate cysts from sediment. $G$. catenatum cysts produced in cultures.

striking differentiating characteristic between the two cyst types was size, since brownish colour was very similar in both. Measurements of the diameters of 289 cysts were taken (Figure 2). All microreticulate cysts were classified into two groups depending bution of $G$. catenatum cysts produced in the laboratory from cultures. The mean size of these cysts was $50 \mu \mathrm{m}(\mathrm{SD}=3.95, \mathrm{n}=108)$.

Differences were also observed in the ornamentation of the outer wall in both types of cysts mentioned. The wall of cysts from the sediment corresponding to the larger size group shows characteristics which are exactly the same as those originally described for G. catenatum (Anderson et al., 1988). Furthermore, both the size and the microreticulation (Figure 3a) are the same as the G. catenatum cysts produced in cultures. When these cysts are compared with the smallest ones ( $G$. catenatum-like cysts, 24-36 $\mu \mathrm{m}$, Figure 3b), differences are noted in microreticulation. The ornamentation of G. catenatum-like cyst walls is formed of a lower number of polygons, which together with the fact that these cysts are far smaller, makes them appear to have a less fine microreticulation than in $G$. catenatum cysts. The paracingulum of the smallest cysts has
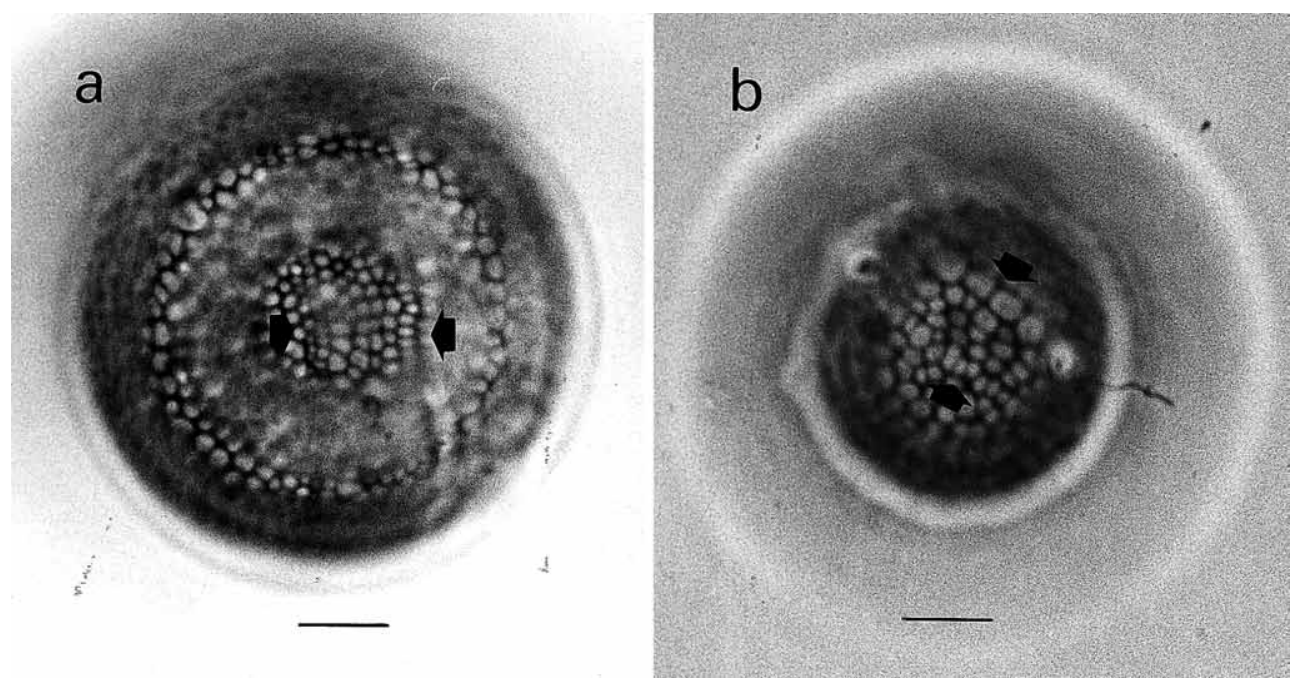

FIG 3. - Microreticulate cysts observed in the sediment from the Galician and Portuguese coast. a) Gymnodinium catenatum cyst $(36-60 \mu \mathrm{m})$. b) small microreticulate cyst $(24-36 \mu \mathrm{m})$. Arrowheads indicate the paracingulum in both cyst types. Bar $=10 \mu \mathrm{m}$.

on size: G. catenatum cysts and small microreticulate cysts ( $G$. catenatum-like cysts). Figure 2 shows a bimodal size distribution which corresponds to the two groups of cysts cited, one centred around 28-30 $\mu \mathrm{m}$ and another at $43-45 \mu \mathrm{m}$, while $36 \mu \mathrm{m}$ was chosen as the diameter of separation between the two. This criterion of classification came out true on all occasions that the microreticulation was tested, though the possibility of a small overlap zone at around $36 \mu \mathrm{m}$ in a very small number of cysts can not be discarded. Figure 2 also shows the size distri- fewer rows of polygons (five rows) than those described for G. catenatum (seven rows). Also, the polygons in the paracingulum are larger in the smallest cysts (up to $3.7 \mu \mathrm{m}$ ) than in $G$. catenatum cysts (up to $2 \mu \mathrm{m}$ ), as can be observed when comparing Figures $3 \mathrm{a}$ and $3 \mathrm{~b}$.

Figure 4 shows the mean concentrations of both types of cysts in the upper $8 \mathrm{~cm}$ of the sediment. The values ranged from $0-504$ cysts $\cdot \mathrm{cm}^{-3}$ and revealed no notable differences between both types of cysts. If, however, the complete vertical profiles are com- 


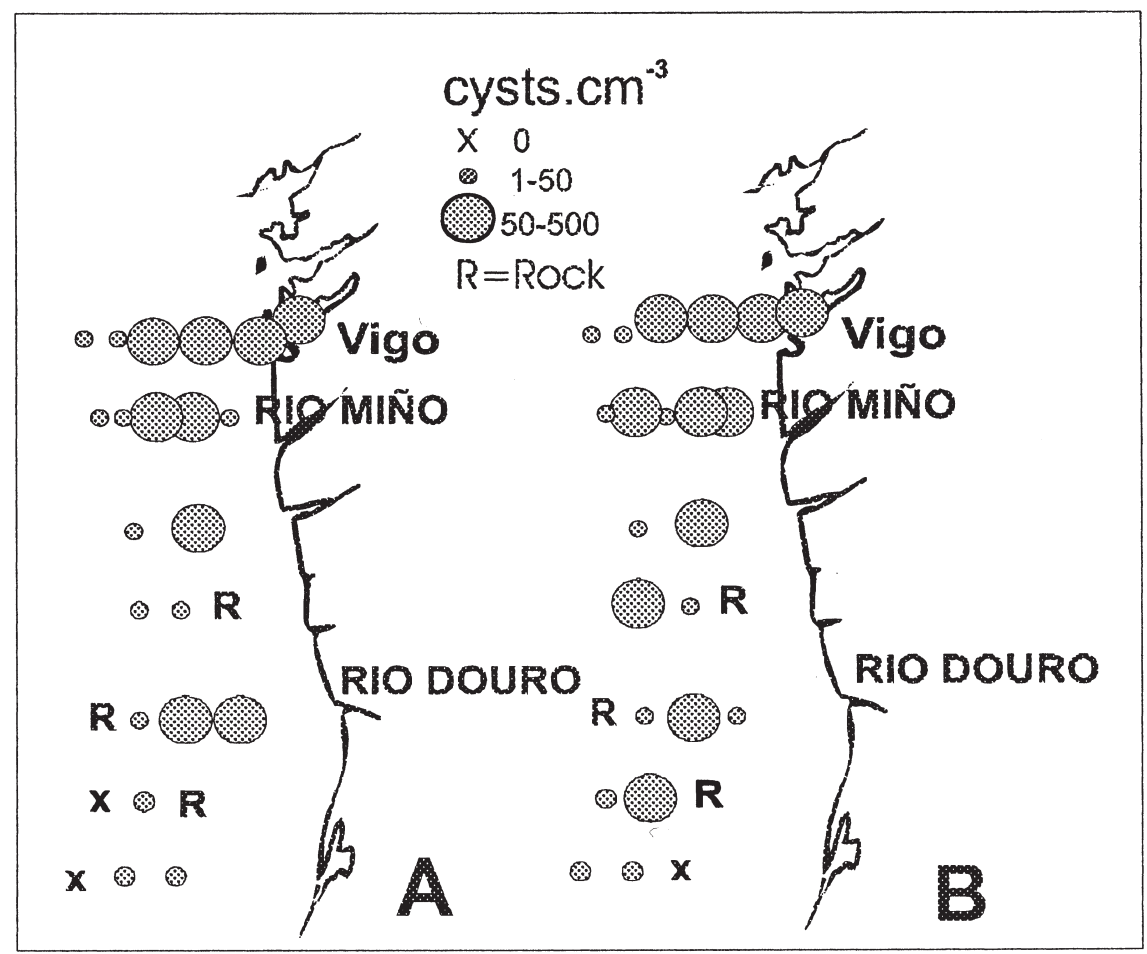

FIG 4. - Concentrations of microreticulate cysts in the upper $8 \mathrm{~cm}$ of the sediment (averaged values). A) $G$. catenatum cysts $(36-60 \mu \mathrm{m})$; B) small microreticulate cysts $(24-36 \mu \mathrm{m})$.

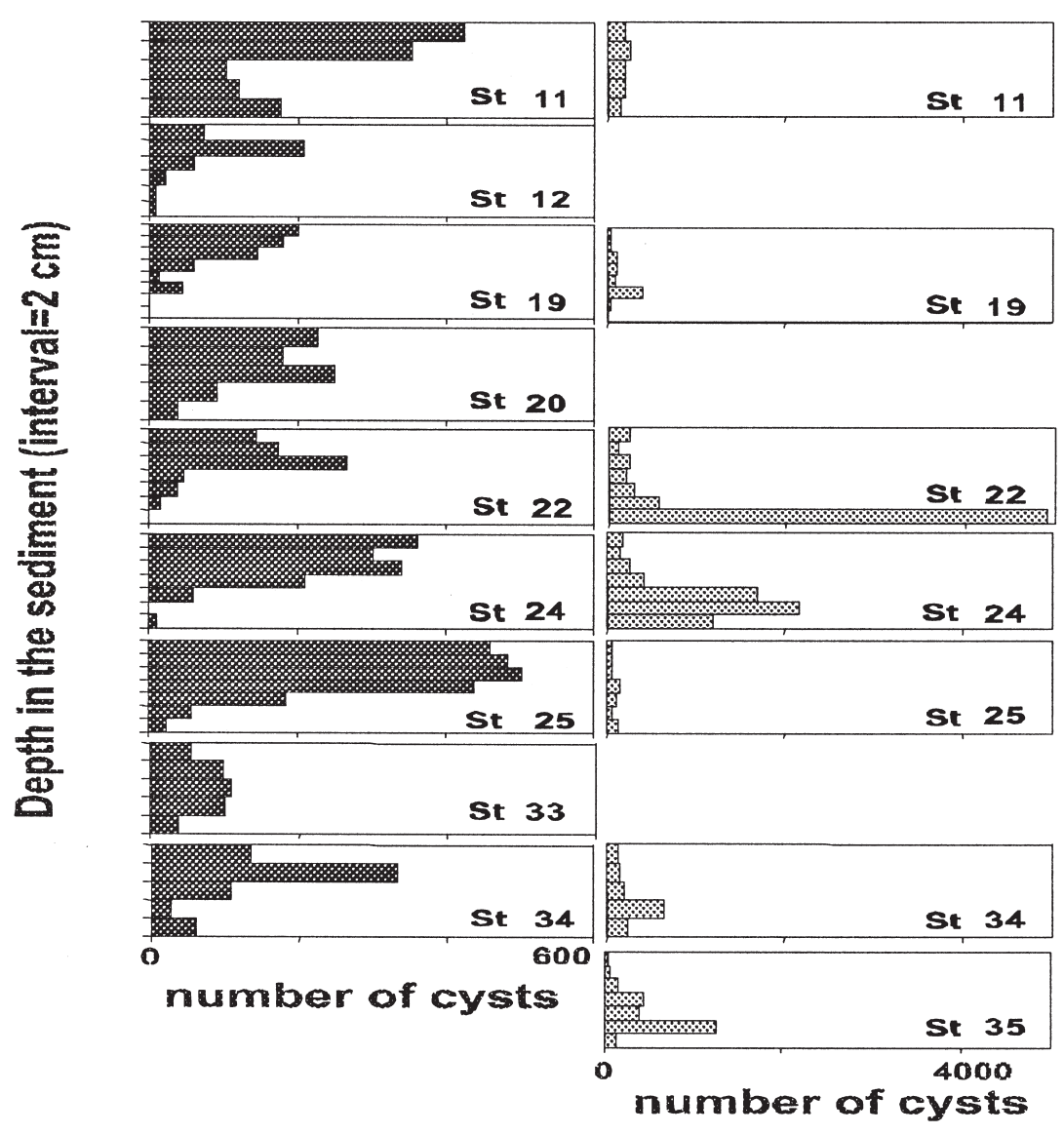

FIG 5. - Vertical distribution of microreticulate cysts in the sediment. G. catenatum cysts $(36-60 \mu \mathrm{m})$; 圈 small microreticulate cysts $(24-36 \mu \mathrm{m})$. 
pared (Figure 5), differences in depth distribution are observed. The concentration of $G$. catenatum cysts $(36-60 \mu \mathrm{m})$ decreases with the depth in the sediment. Conversely, in the case of the small cysts (24-36 $\mu \mathrm{m})$, the concentration is either uniform or shows a clearly defined increase in the sediment (Figure 5, see stations 22 and 24). The highest concentrations for the smaller $36 \mu$ m cysts were below $8 \mathrm{~cm}$.

In the case of $G$. catenatum cysts, the maximum concentration achieved was 504 cysts $\mathrm{cm}^{-3}$ of sediment at station number 25, off the Ría of Vigo at a sediment depth of 4-6 cm (Figure 5). G. catenatum cysts accounted for $38 \%$ of the total cysts. In the case of the smallest cysts, the maximum concentration was $4488 \mathrm{cysts}^{\cdot} \mathrm{cm}^{-3}$ at station 22 , and at $12-14$ $\mathrm{cm}$ depth, accounting for $88 \%$ of the total.

\section{DISCUSSION}

Widely varying interpretations may be deduced from the data presented here, depending on the identity of the microreticulate cysts. The authentic $G$. catenatum cysts identified were not over 504 cysts $\mathrm{cm}^{-3}$ of sediment. The smallest microreticulate cysts presented concentrations of up to 4488 cysts $\cdot \mathrm{cm}^{-3}$. Due to the fact that these high concentrations were found in depths of sediment of over $8 \mathrm{~cm}$, the likelihood that they are involved in the initiation of a bloom appears low, whether they are G. catenatum or otherwise. It may be deduced, however, that the species (or G. catenatum morphotypes) to which the G. catenatum-like cysts belong was more abundant in previous decades. Also, the concentrations of cysts appear to reflect that the current form of $G$. catenatum is gradually becoming more abundant in these waters.

Blanco (1989) refers to two types of cyst in sediment from Galicia, which differ in size and are very similar to G. catenatum. The cyst he describes for this species appears to have more in common with what is termed G. catenatum-like in this article. The cysts mentioned by Bravo and Anderson (1994) in the cyst distribution data on this dinoflagellate in the Ria of Vigo (Galicia, Spain) we consider as belonging to the group identified as $G$. catenatum, i.e. in the 36-60 $\mu \mathrm{m}$ size range (Bravo, unpublished data). Although the role of G. catenatum cysts is unknown in the bloom dynamics of this species in the western coast of the Iberian Peninsula, it would be important to be able to quantify the cysts in the sediment in the area. The description of G. catenatum cysts involved a step forward in the study of the bloom dynamics of this species. At present, however, it is necessary to clarify and differentiate the various types of cysts with microreticulation in the wall since there may be cases of erroneous identifications that could lead to mistaken interpretations.

In the literature where reference is made to $G$. catenatum cysts, both types of cysts mentioned in this text are also cited. There are descriptions which correspond exactly to the original description of the G. catenatum cyst, such as the description by Blackburn et al., (1989) and Bolch and Hallegraeff (1990) for cysts observed in sediment from Tasmania. In that country, however, the last authors mentioned also refer to a cyst very similar, but smaller (17-22 $\mu \mathrm{m})$ which they referred to as Gymnodium sp 1. Recently Bolch et al., 1998 has also reported a widespread distribution of three distinct size morphotypes of microreticulate cysts: the largest type (43$56 \mu \mathrm{m}$ ) corresponds to G. catenatum cysts, a "smallform" $(17-28 \mu \mathrm{m})$ that produced small vegetative cells of a non-chain-forming Gymnodinioid genetically distinct from $G$. catenatum and an "intermediate-form" $(36-43 \mu \mathrm{m})$ of cysts that germinated in typical chain-forming cells similar to those of $G$. catenatum.

The microreticulate cyst mentioned by several authors from Northern Europe and identified as $G$. catenatum due to its characteristic microreticulate wall is also undergoing revision. Ellegaard et al., (1993) and Nehring, (1995) refer to G. catenatum cysts in sediment from the Danish and German coast, and Dale et al., (1993) refers to a fossil cyst of this dinoflagellate in Scandinavian sediment. Recently Ellegaard and Moestrup (in press) describe the vegetative cells produced by germinating microreticulate cysts from Danish marine sediments as a new species named Gymnodinium nolleri Ellegaard et Moestrup sp. ined. These authors separate this species and G. catenatum on the basis of molecular sequencing, ultrastructure of the flagellar root system and morphological differences between the two cysts and vegetative cells. There would seem to be two species of dinoflagellates with microreticulate cysts already described: G. catenatum and $G$. nolleri. Besides, the Australian small-form cysts belong to other species which must be described (Bolch et al.,1998).

The cysts size, colour and the characteristics of the paracingulum microreticulation of the smallest G. catenatum-like cysts we describe in the present 
publication appear to be very similar to $G$. nolleri cysts described by Ellegaard and Moestrup (in press). To date, our attempts to germinate small $G$. catenatum-like cysts have been unsuccessful and since the species with microreticulate cysts are still not known definitively we are unable to determine which species we are dealing with. Nevertheless, further efforts should be made in order to be able to compare and distinguish between different dinoflagellate species producing a microreticulate cyst.

\section{ACKNOWLEDGEMENTS}

This work was supported by the projects: MAR95-1849 (CICYT, Spain) and MAST2-CT930065"MORENA" (European Union).

\section{REFERENCES}

Anderson, D.M., D.M. Jacobson, I. Bravo and J.H. Wrenn. - 1988. The unique, microreticulate cyst of the naked dinoflagellate Gymnodinium catenatum. J. Phycol. 24: 255-262.

Blackburn, S.I., G..M. Hallegraeff, C.J. Bolch. - 1989. Vegetative reproduction and sexual life cycle of the toxic dinoflagellate Gymnodinium catenatum from Tasmania, Australia. J. Phycol. 25: $577-590$

Blanco, J. - 1986. Separación de quistes de dinoflagelados en gradiente de densidad. Bol. Ins. Esp. Oceanogr. 3: 81-84.

Blanco, J. - 1989. Quistes de dinoflagelados de las costas de Galicia. III. Dinoflagelados Gymnodinioides. Scient. Mar. 53: 813819.

Bolch, C.J., G.M. Hallegraeff. - 1990. Dinoflagellate cysts from recent marine sediments of Tasmania, Australia. Bot. Mar. 33: 173-192.
Bolch, C.J., G.M. Hallegraeff, S. Hardiman. - 1998. Micro-reticulate cysts of gymnodinoid dinoflagellates: Morphology and genetic relationships. In: M. Smelror (ed.): Abstracts from the Sixth International Conference on Modern and Fossil Dinoflagellates Dino 6, Trondheim Rapport botanisk serie 1: 18, Norges teknisk-naturvidenskabelige universitet Vitenskabsmuseet, Trondheim.

Bravo, I., D.M. Anderson. 1994. - The effects of temperature, growth medium and darkness on excystment and growth of the toxic dinoflagellate Gymnodinium catenatum from northwest Spain. J. Plankton Res.16: 513-525.

Bravo, I., J.M. Franco, M.I. Reyero. - 1998. PSP toxin composition of three life cycle stages of Gymnodinium catenatum. In: B. Reguera, J. Blanco, M. Fernandez and T. Wyatt (eds): Harmful and Toxic Algal Blooms, pp. 356-358. IOC of Unesco, Vigo, España.

Dale, B., A. Madsen, K. Nordberg, T.A. Thorsen. - 1993. Evidence for prehistoric and historic "blooms" of the toxic dinoflagellate Gymnodinium catenatum in the Kattegat-Skagerrak region of Scandinavia. In: Smayda, T.J. and Shimizu, Y. (eds): Toxic Phytoplankton Blooms in the Sea, pp. 47-52. Elsevier, New York.

Ellegaard, M., N.F. Christensen, Ø. Moestrup. - 1993. Temperature and salinity effects on growth of a non-chain-forming strain of Gymnodinium catenatum (Dinophyceae) established from a cyst from recent sediments in the Sound (Øresund), Denmark. J. Phycol., 29: 418-426.

Ellegaard, M., Ø. Moestrup, - in press. Fine structure, with emphasis on the flagellar apparatus, and morphological details of Gymnodinium nolleri (Dinophyceae) sp. nov.- an unarmoured dinoflagellate producing a microreticulate cyst. Phycologia.

Hallegraeff, G.M., S. Fraga. - 1998. Bloom dynamics of the toxic dinoflagellate Gymnodinium catenatum, with emphasis on Tasmanian and Spanish coastal waters. In: D.M. Anderson, A.D. Cembella and G.M. Hallegraeff (eds): Physiological Ecology of Harmful Algal Blooms, pp. 59-80. Springer-Verlag, Berlin.

Matsuoka, K., Y. Fukuyo. - 1994. Geographical distribution of the toxic dinoflagellate Gymnodinium catenatum Graham in Japanese coastal waters. Bot. Mar. 37: 495-503.

Nehring, S. - 1995. Gymnodinium catenatum Graham (Dinophyceae) in Europe: a growing problem? J. Plankton Res. 17: 85-102.

Utermöhl, H. - 1958. Zur Verkollkommung der quantitativen Phytoplankton-Methodik. Mitt. Int. Ver. Theor. Angew. Limnol. 9: $1-38$.

Scient. ed.: M. Estrada 